International Journal of Current Advanced Research

ISSN: O: 2319-6475, ISSN: P: 2319 - 6505, Impact Factor: SJIF: 5.995

Available Online at www.journalijcar.org

Volume 6; Issue 4; April 2017; Page No. 3303-3305

DOI: http://dx.doi.org/10.24327/ijcar.2017.3305.0256

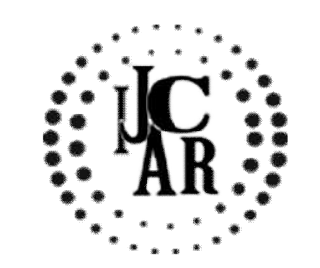

Research Article

\title{
ABILITY OF DENTAL STUDENTS TO IDENTIFY POTENTIALLY MALIGNANT DISEASES AND ORAL CANCERS - A QUESTIONNAIRE BASED STUDY
}

\section{Harshini Ravichandran and Gifrina}

Saveetha Dental College and Hospital, Chennai

\begin{tabular}{|c|c|}
\hline A R T I C L E I N F O & A B S T R A C T \\
\hline Article History: & Potentially malignant disorder and oral cancer is a major health problem especially in \\
\hline $\begin{array}{l}\text { Received } 17^{\text {th }} \text { January, } 2017 \\
\text { Received in revised form } 10^{\text {th }} \text { February, } 2017 \\
\text { Accepted } 22^{\text {nd }} \text { March, } 2017 \\
\text { Published online } 28^{\text {th }} \text { April, } 2017\end{array}$ & $\begin{array}{l}\text { developing countries, and a serious cause of morbidity and mortality worldwide. It is } \\
\text { believed that the etiology of oral cancer is multifactorial and that the process is a multiple, } \\
\text { stepwise one. Most of the times oral cancer is preceded by a precancerous state where the } \\
\text { patient presents clinical features depicting potentially malignant disorders. Thereby } \\
\text { identification in these state would help in successful treatment and preventing it from }\end{array}$ \\
\hline Key words: & $\begin{array}{l}\text { oral cancer will improve the efficacy of prevention, screening and management of this } \\
\text { lesion. }\end{array}$ \\
\hline
\end{tabular}

Diseases and oral cancers

Copyright $₫ 2017$ Harshini Ravichandran and Gifrina. This is an open access article distributed under the Creative Commons Attribution License, which permits unrestricted use, distribution, and reproduction in any medium, provided the original work is properly cited.

\section{INTRODUCTION}

Oral cancer is the 6th most common cause of cancer-related deaths worldwide [1]. Squamous cell carcinoma accounts for more than $90 \%$ of oral cancers [2]. The main identifiable risk factors for oral cancer are largely preventable and include tobacco, alcohol, and betel [3]. Infection with human papilloma virus is implicated in a subset of oropharyngeal cancers, and excessive exposure to sunlight is linked to lip cancer [4]. Other possibly implicated factors include immune suppression, poor nutrition, familial and genetic predisposition [4]. Early oral cancer usually presents as a nonhealing ulcer, red patch, white patch, or persistent lump [5]. Some oral cancers are asymptomatic and some are preceded by noticeable oral lesions known as oral potentially malignant disorders (OPMDs) [6]. Erythroplakia, leukoplakia, and lichenoid lesions are the most important OPMDs, but several other oral lesionsorconditionsmay be associated with an increased risk of oral cancer [7]. The prognosis of early stage oral cancer is good, but most oral cancers, even in developed countries, present at late stages and invariably have a poor prognosis [8]. Early recognition of oral cancer and OPMDs remains the most effective approach to control the morbidity and mortality associated with this disease [7]. Delays in oral cancer diagnosis have been attributed mainly to patients' delay in seeking help and professionals' delay in making diagnosis $[9,10]$. Generally, early oral cancer is asymptomatic andfeeling discomfort is the

*Corresponding author: Harshini Ravichandran

Saveetha Dental College and Hospital, Chennai typical sign in $85 \%$ of cases. Therefore most of oral cancers are diagnosed in advanced stages when clinical signs appear [11].Therefore, despite improvements in SCC treatment, the 5 -year survival rate has not been considerably raised since 50 years ago [12]. Early diagnosis of malignant lesions is an everlasting target which demands dentists' knowledge.

In addition to giving a natural life length to people [13]. Dentists can increase their patient's information about oral cancer. This increase in information can lead to decrease of risk factors, early diagnosis and increasing the survival rate in patients [14]. This target will realize via correct theoretical and practical education of oral cancer including identification of various malignant lesions, its etiologic factors, and accurate examination of all patients, especially those aged 40 and more [15]. Inadequate knowledge and detection practices of health care professionals might contribute to the delayed diagnosis oforal cancer [16]. Dental students are the future dental health care workforce whose awareness of and knowledge about oral cancer has been well documented in the literature [17]. However, little is known about their oral cancer diagnostic ability and factors that might influence it. We have recently shown that the diagnostic ability of primary health care professionals is directly correlated with their knowledge about oral cancer and might influence their early detection practices [18]. In the present study, therefore, we aimed to examine the diagnostic ability of dental students with regards to oral cancer and OPMDs.

\section{MATERIALS AND METHOD}

The study was conducted at our dental school during the academic year 2015-2016. Dental students at our school are 
enrolled in a 4-year training program; the 1st year includes basicbiologicalsciences, and second year sincludebasic medical and dental sciences, and 3th and 4th years include clinical medical and dental sciences. Students of the 3rd and 4th year levels were approached to participate in the study.A questionnaire is distributed to 50 dental studying in a private dental institution, Chennai. The questionnaire contained 20 pictures presenting various lesions. The 20 pictures consisted PMDs, oral cancer and normal lesions also. The students were analysed based on their ability to identify these lesions.

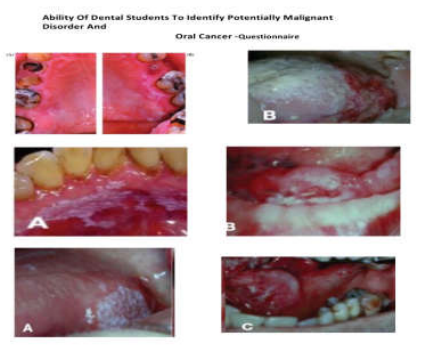

Fig 1

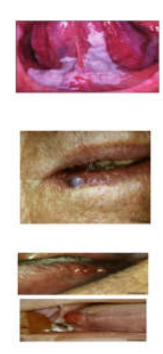

Fig 2 ability among dental students. At our school, students are mainlyintroducedtoknowledgeaboutoraldiseasesincluding oral cancer and OPMDs in oral pathology and oral medicine courses during their 4th and 5th years of study. The current teaching methods of oral medicine and oral pathology at our schoolhavebeenlargely based onlecturesand group seminars with practical/clinical components. In the present study, we approached students of the $3 \mathrm{rd}$, and 4th year levels in order to examine the effectiveness of current teaching methods on students' knowledge and diagnostic ability with regard to oral
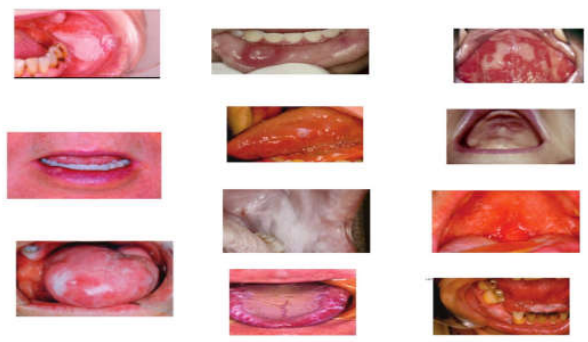

Fig 3

\section{RESULTS}

All dental students in the $3^{\text {rd }}$ and 4 th years of study were approached to participate in the study. A total of 50 students were approached and most agreed to participate. Only $58.45 \%$ of students were efficient in identifying the lesions correctly. This study reveals areas of deficiency in the awareness of dental undergraduates in the field of oral cancer and OPMD. The least identity field was one among pictures of leukoplakia. The most identified is lesson with mucosal atrophy and faint leukoplakia.
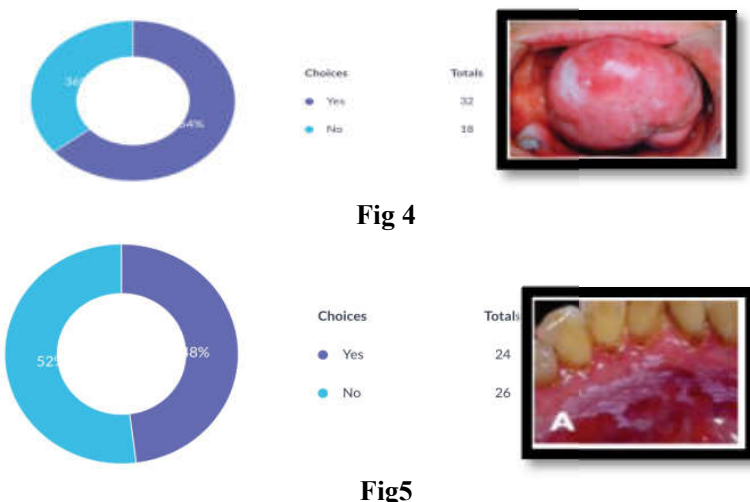

Fig 4

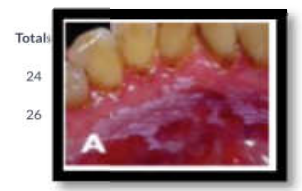

Fig5

Table 1

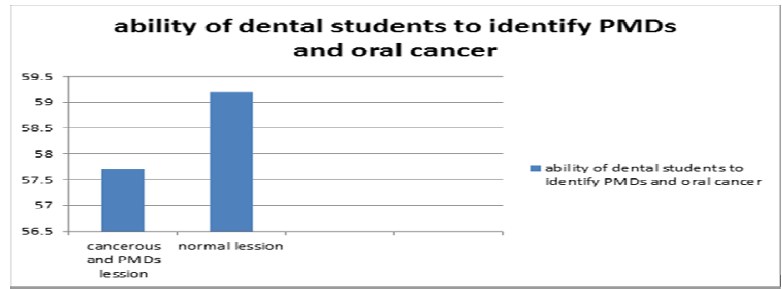

DISCUSSION

Dental students are the future healthcare workforce with the responsibility for oral cancer diagnosis and patient education though other healthcare professionals may contribute. The presentstudyexaminedoralcancer knowledge and diagnostic cancer and OPMDs. Expectedly, theoretical knowledge about oral cancer improved proportionally with year of studys incemore in formation is given through various lectures and seminars [19]. This effect, however, was less pronounced with regard to diagnostic ability; probably because students have a limited exposure to patients with oral lesions during their training in oral pathology andoral medicine. In fact, most senior dental students felt that the training they had received during their years of study was inadequate for heirconfidentdiagnosisoforallesionsincluding OPMDs and oral cancer, and that they need further training in this field. Increasing student contact with patients with various oral lesions including oral cancer might help improve their diagnostic skills.

\section{CONCLUSION}

Interventions to improve students' knowledge about risk factors, diagnostic techniques, early diagnosis and referral of oral cancer are needed. Increasing students' contact with patients who have oral lesions including oral cancer will help to improve their future diagnostic ability and early detection practices. This study reveals areas of deficiency in the awareness of medical and to some extent dental undergraduates in the field of oral cancer and particularly OPMD. It is of utmost importance that these aspects of medical and dental undergraduate curricula are strengthened in order to produce medical doctors and dentists of tomorrow who would play committed and confident roles in prevention and early detection of oral cancer and OPMD.

\section{References}

1. Siegel RL, Miller KD, Jemal A. Cancer statistics, 2016. CA Cancer J Clin 2016; 66(1):7-30. doi:10.3322/caac. 21332

2. Ferlay J, Soerjomataram I, Dikshit R, Eser S, Mathers $\mathrm{C}$, Rebelo $\mathrm{M}$ et al. Cancer incidence and mortality worldwide: sources, methods and major patterns in 
GLOBOCAN 2012. Int J Cancer. 2015; 136(5):E35986. doi:10.1002/ijc. 29210

3. Boing AF, Peres MA, Antunes JL. Mortality from oral and pharyngeal cancer in Brazil: trends and regional patterns, 1979-2002. Rev PanamSaludPublica. 2006; 20(1):1-8. doi:10.1590/S1020-49892006000700001

4. Warnakulasuriya S. Living with oral cancer: epidemiology with particular reference to prevalence and life-style changes that influence survival. Oral Oncol. 2010; 46(6):407-10. doi: 10.1016/j. oraloncology.2010.02.015

5. Carvalho AL, Nishimoto IN, Califano JA, Kowalski LP. Trends in incidence and prognosis for head and neck cancer in the United States: a site-specific analysis of the SEER database. Int J Cancer. 2005; 114(5):806-16. doi:10.1002/ijc.20740

6. Howlader NNA, Krapcho M, Garshell J, Miller D, Altekruse SF, Kosary CL et al., editors. SEER cancer statistics review, 1975-2013. Bethesda, MD: National Cancer Institute; 2015. p. 1975-2012.

7. Visscher JG, Waal I. Etiology of cancer of the lip: a review. Int J Oral MaxillofacSurg. 1998; 27(3):199203. doi:10.1016/S0901-5027(98)80010-6

8. Håkansson N, Floderus B, Gustavsson P, Feychting M, Hallin N. Occupational sunlight exposure and cancer incidence among Swedish construction workers. Epidemiology. 2001; 12(5):552-7. doi: 10. 1097 / 0000 1648-200109000-00015

9. Spitzer WO, Hill GB, Chambers LW, Helliwell BE, Murphy HB. The occupation of fishing as a risk factor in cancer of the lip. N Engl J Med. 1975; 293(9):41924. doi:10.1056/NEJM197508282930903

10. Cancer Research UK. Oral cancer incidence statistics. London: Cancer Research UK; 2015 [cited 2015 Sep]. Available from: http://www.cancerresearchuk.org/ health-professional/cancer-statistics/ statistics-bycancer-type/oral-cancer/incidence
11. Sargeran K, Murtomaa H, Safavi SM, Vehkalahti MM, Teronen O. Survival after lip cancer diagnosis. $J$ CraniofacSurg. 2009; 20(1):248-52. doi:10.1097/ SCS. 0b013e31818431bd

12. Moore S, Johnson N, Pierce A, Wilson D. The epidemiology of lip cancer: a review of global incidence and aetiology. Oral Dis 1999; 5(3):185-95. doi:10.1111/j.1601-0825.1999.tb00300.x

13. Neville BW, Day TA. Oral cancer and precancerous lesions. CA Cancer J Clin. 2002; 52(4):195-215. doi:10.3322/canjclin.52.4.195

14. Osterne RL, Costa FW, Mota MR, Vidal Patrocínio RM, Alves AP, Soares EC et al. Lip lesions in a Brazilian population. J CraniofacSurg. 2011; 22(6):2421-5. doi:10.1097/SCS.0b013e318232a7dc

15. Yellowitz JA, Horowitz AM, Drury TF, Goodman HS. Survey of U.S. dentists' knowledge and opinions about oral pharyngeal cancer. J Am Dent Assoc. 2000; 131:653-61.

16. Colella G, Gaeta GM, Moscariello A, Angelillo IF. Oral cancer and dentists: knowledge, attitudes, and practices in Italy. Oral Oncol. 2008; 44:393-9.

17. Seoane J, Warnakulasuriya S, Varela-Centelles $P$, Esparza G, Dios PD. Oral cancer: experiences and diagnostic abilities elicited by dentists in Northwestern Spain. Oral Dis. 2006; 12:487-92.

18. Pentenero M, Carrozzo M, Pagano M, Galliano D, Broccoletti R, Scully C, et al. Oral mucosal dysplastic lesions and early squamous cell carcinomas: underdiagnosis from incisional biopsy. Oral Dis. 2003; 9:68-72.

19. Reed M, Claffey N, Allen B, Beeley J, Beemsterboer $\mathrm{P}$, Carrassi A, et al. 2.3 Towards global convergence of education, training, quality, outcome and assessment. Eur J Dent Educ. 2002; 6 Suppl 3:7883.

\section{How to cite this article:}

Harshini Ravichandran and Gifrina (2017) ' Ability Of Dental Students To Identify Potentially Malignant Diseases And Oral Cancers - A Questionnaire Based Study', International Journal of Current Advanced Research, 06(04), pp. 3303-3305. DOI: http://dx.doi.org/10.24327/ijcar.2017.3305.0256 